\title{
Time-Cumulative Toxicity of Neonicotinoids: Experimental Evidence and Implications for Environmental Risk Assessments
}

\author{
Francisco Sánchez-Bayo ${ }^{1, *}$ and Henk A. Tennekes ${ }^{2,+}$ \\ 1 School of Life and Environmental Sciences, The University of Sydney, Eveleigh, NSW 2015, Australia \\ 2 ETS Nederland BV, Frankensteeg 4, 7201KN Zutphen, The Netherlands; info@toxicology.nl \\ * Correspondence: francisco.sanchez-bayo@sydney.edu.au or sanchezbayo@mac.com; Tel.: +61-2-448-664-680 \\ † Current address: Laan van Hilbelink 95-113, 7101WL Winterswijk, The Netherlands.
}

Received: 4 February 2020; Accepted: 28 February 2020; Published: 3 March 2020

\begin{abstract}
Our mechanistic understanding of the toxicity of chemicals that target biochemical and/or physiological pathways, such as pesticides and medical drugs is that they do so by binding to specific molecules. The nature of the latter molecules (e.g., enzymes, receptors, DNA, proteins, etc.) and the strength of the binding to such chemicals elicit a toxic effect in organisms, which magnitude depends on the doses exposed to within a given timeframe. While dose and time of exposure are critical factors determining the toxicity of pesticides, different types of chemicals behave differently. Experimental evidence demonstrates that the toxicity of neonicotinoids increases with exposure time as much as with the dose, and therefore it has been described as time-cumulative toxicity. Examples for aquatic and terrestrial organisms are shown here. This pattern of toxicity, also found among carcinogenic compounds and other toxicants, has been ignored in ecotoxicology and risk assessments for a long time. The implications of the time-cumulative toxicity of neonicotinoids on non-target organisms of aquatic and terrestrial environments are far reaching. Firstly, neonicotinoids are incompatible with integrated pest management (IPM) approaches and secondly regulatory assessments for this class of compounds cannot be based solely on exposure doses but need also to take into consideration the time factor.
\end{abstract}

Keywords: time-dependent toxicity; bees; non-target arthropods; ecological risks; time-to-event bioassays

\section{Introduction}

Neonicotinoids are the most commonly used insecticides in the world, comprising a third of the world market of insecticides [1]. Since the introduction of the first neonicotinoid, imidacloprid, on the market in 1991 several new compounds with the same mode of action have been developed and commercialised for a wide range of uses: from agricultural pest control in more than 150 different crops and extensive use in animal husbandry (i.e., parasite control on sheep) to parasite control in domestic pets and termite control [2].

The key to their success is not only the specificity of action against insects and other arthropods but also their versatility, since neonicotinoids are systemic chemicals that can be applied not only as sprays over the crops but also as soil drenches, soil granules and seed-coatings [3]. In fact, the latter has become the most widely used form of application in agriculture, particularly among broad-acre crops such as cotton, maize, oilseed-rape (canola), sugarcane and sunflower, since the water solubility and chemical properties of neonicotinoids ensure their diffusion within treated plants by xylemic and phloemic transport. In addition, it is mainly for this reason that they also impact the environment of the applied areas and beyond, due to their high mobility in soil and contamination of ground- and surface water [4]. 
To evaluate the environmental impacts of neonicotinoids requires an understanding of the particular mode of action and toxicity of these chemicals. This constitutes the objective of this paper. Neonicotinoids are agonists of the nicotinic acetylcholine receptors (nAChR) that are present in the post-synaptic membranes of all neuronal cells of animals, vertebrates and invertebrates alike. Neonicotinoids bind specifically to the $\alpha 4 \beta 2$ subunit of these receptors, which is the common nicotinic subunit in all insects, whereas it makes up only a small fraction of the vertebrates' nAChRs [5]. For this reason, neonicotinoids are selective insecticides that display much lower acute toxicity towards vertebrates [6].

Neonicotinoid molecules compete with the natural neurotransmitter acetylcholine for the same receptors, but with one important difference: while acetylcholine is immediately released and metabolised by the enzyme acetylcholine esterase after binding, neonicotinoids cannot be metabolised by this enzyme and remain bound to the receptors. Consequently, the activation of the receptors by neonicotinoids is not temporary but rather permanent, as the xenobiotic molecules block irreversibly the nAChRs, thus leading to a lethal hyperactivity of the nerves and muscles of the insect [7]. This mode of action elicits a continuous excitation that results in convulsions, trembling, paralysis, and physiological damage, eventually causing the death of the neurons and muscles. These lethal effects are obviously irreversible and different from the behavioural effects, such as feeding inhibition, also observed with some neonicotinoids [8]. However, the reversibility of some behavioural effects induced by imidacloprid cannot be regarded as sufficient evidence for the reversibility of neuronal injury, as they could be due to adaptive processes in surviving neurons-other neonicotinoids do not induce feeding inhibition.

However, the fact that insects and other animals poisoned with low exposure levels of neonicotinoids do not die immediately but rather after prolonged exposure has been described as 'delayed toxicity' [9]—as opposed to the typical acute lethality caused by other toxic chemicals—and suggests that the lethal effect of neonicotinoids occurs after the animal has surpassed a critical level of neuronal deaths $[10,11]$. Such lethal neuronal threshold may be reached in a few hours when animals are exposed to high levels of the chemical or may take days when the exposure concentrations are low-hence the appropriateness of the term 'delayed'. Consequently, the toxicity of neonicotinoids should not be understood only in terms of acute lethality but must be considered within a chronic framework, as the time to cause a lethal effect can be stretched several days. This pattern, derived from the particular mode of action of these chemicals, is referred to as time-cumulative or time-reinforced toxicity [12].

This pattern of toxicity may be regarded as unusual for insecticides, which are typically chemicals with high acute toxicity, but is nevertheless quite common among other substances. Its theoretical basis was proposed by Druckrey and Küpfmüller in the 1940s [13], and has been confirmed experimentally for several carcinogenic chemicals [14,15], rodenticides [16], the succinate dehydrogenase inhibiting (SDHI)-fungicide boscalid [17], and elementary toxicants such as mercury [18]. We have previously described in detail this pattern of toxicity and indicated a simple way to identify it [10]. In this paper, we only provide a brief description of the mechanisms involved, while focusing mainly on the experimental evidence that demonstrates that neonicotinoids follow such a pattern, with the consequences this entails for a proper risk assessment of these chemicals [19].

\section{Time-Dependent Toxicity}

The classical foundation of toxicology that the 'dose makes the poison' (Dosis facit venenum, Paracelsus) acquired a second dimension when Fritz Haber established that time of exposure determines the effective toxic dose. Haber's rule, which establishes that the dose that causes a toxic effect (E) is the product of the applied dose (d) and the time of exposure $(t): E=d \times t$, set the basis for a better understanding of the toxicity of chemicals, and was later analysed and explained mathematically by Druckrey and Küpfmüller [13]. The theoretical work of the latter authors gave a solid foundation 
to the toxicological science, enabling the prediction of effects with prolonged exposure to chemicals, predictions that were later confirmed empirically.

The underlining assumptions of the Druckrey-Küpfmüller theorem apply to chemicals with specific mode of action such as pesticides targeting enzymes and/or receptors within particular metabolic pathways [20]. As a description of their theorem is outside the scope of this paper, the reader is referred to Tennekes and Sánchez-Bayo 2013 [10] for a complete explanation. Here we summarise the main points that need to be considered for understanding the time-dependent toxicity of neonicotinoids and other toxic chemicals. As neonicotinoids are known to interact with nACh receptors, we use the term receptor, but this description may actually apply to any target molecule where interaction may result in a toxic effect, such as enzymes, DNA, structural proteins, etc. For ease of explanation, we use concentrations instead of doses applied.

A toxicant molecule interacts with a receptor in a bimolecular reaction and the relative concentration of bound receptors $\left(C_{R} / R_{0}\right)$ is assumed to determine the effect. Experimentally, the measured effect is typically used as a proxy of the extent of the interactions, since the proportion of bound receptors cannot be measured directly [21].

The kinetics of receptor binding are governed by two rate constants: the time constant for association $\mathrm{T}_{\mathrm{A}}$ and the time constant for dissociation $\mathrm{T}_{\mathrm{R}}$. In a steady-state equilibrium, it can be demonstrated that the relative concentration of bound receptors $\left(C_{R} / R_{0}\right)$ is

$$
\frac{C_{R}}{R_{0}}=\frac{\left[C / R_{0}\right] \cdot\left[T_{R} / T_{A}\right]}{1+\left[C / R_{0}\right] \cdot\left[T_{R} / T_{A}\right]}
$$

where $C$ is the concentration at the site of action, which results from the equilibrium between the external and internal concentrations of the toxicant. Please note that in laboratory toxicity tests, the external concentration (c) is assumed to be proportional to the concentration at the site of action C. Equation (1) indicates that the relationship between the relative concentration of bound receptors $\left(C_{R} / R_{0}\right)$ and the relative toxicant concentration $\left(C / R_{0}\right)$ follows a hyperbolic curve, with saturation of the receptors at very high concentrations (see Figure 2 in [10]). The ratio $T_{R} / T_{A}$ determines the strength of the binding and, therefore, of the toxic effect: the higher the ratio, the higher the toxicity. Consequently, substances with large $T_{R} / T_{A}$ ratios require small relative toxicant concentrations $\left(C / R_{0}\right)$ to produce an effect, whereas those with ratios below 1 require higher relative toxicant concentrations.

Furthermore, the speed in producing an effect depends on the values of the time constants. Low values of $T_{R}$ and $T_{A}$ indicate that both association and dissociation are fast processes, with the toxic effect appearing quickly and the recovery being also quick; the maximum effect will occur when the concentration at the site of action $C$ is highest, and effects will be dependent almost exclusively on concentration. However, a high value of the dissociation constant $T_{R}$ indicates the interaction is slowly reversible, implying that the binding will last a long time. The maximum effect in this case will be delayed as the equilibrium between $C$ and receptor binding will take some time. A high value of the dissociation constant $T_{R}$ will therefore make toxicity time-dependent. A period of latency may occur in which no toxic effects are observed until the proportion of bound receptors $C_{R}$ reaches a certain threshold.

Of particular interest is the case of toxicants that show irreversible binding to the target receptor, as it is found with neonicotinoids [7], organophosphorus compounds [22,23], synthetic pyrethroids [24], rodenticides inhibitors of vitamin K [16], herbicides inhibitors of photosynthetic pathways or other enzymes [25], and various fungicides and biocides [20]. In such cases, the dissociation constant $T_{R}$ approaches infinity. If the concentration at the site of action $C$ is constant, as it happens whenever exposure concentration $\mathrm{c}$ is kept constant throughout a laboratory study, and assuming the bulk of receptors in the organism are not bound to the toxicant (i.e., when $C_{R}<<R_{0}$, first-order kinetics) then Equation (1) reduces to

$$
\frac{C_{R}}{R_{0}}=K C t
$$


here $\mathrm{K}$ is the velocity of the process and has the dimension of reciprocal of time. Assuming also there is proportionality between the concentration at the site of action $\mathrm{C}$ and the effect $\mathrm{E}$, then

$$
E=K C t
$$

and the toxicant will follow Haber's rule. In this case, the velocity of the effect (E/t) would be linearly related to the concentration at the site of action $C$, while the concentration of bound receptors $C_{R}$ would be proportional to the integral of $\mathrm{C}$ over time:

$$
C_{R} \sim \int C d t
$$

If the subsequent effect happens to be irreversible as well, the effect $\mathrm{E}$ would be proportional to the integral of the concentration of bound receptors $C_{R}$ over time:

$$
E \sim \int C_{R} d t
$$

When a toxicant has irreversible binding to a receptor and the effect produced is also irreversible (e.g., death), the effect $\mathrm{E}$ would be proportional to the double integral of the concentration at the site of action C over time, as the combination of Equations (4) and (5) shows:

$$
E \sim \iint C d t
$$

The implication of Equation (6) is that exposure time will enhance the effect $\mathrm{E}$ for a given concentration $\mathrm{C}$. Integration of Equation (6) results in $\mathrm{E}=\mathrm{C} \times \mathrm{t}^{2}$.

Haber demonstrated empirically the validity of Equation (3) using nerve gas in experimental animals, and Druckrey and colleagues demonstrated also empirically that Equation (6) holds true in the case of the carcinogenic substances such as 4-dimethylaminostilbene (4-DAST), diethylnitrosamine (DENA) and ethyl-nitrosurea (ENU) $[14,15,26]$. As the effect of time was more than quadratic in some of their experimental studies, the general form of the Druckrey-Küpfmüller equation is $C \times t^{n}=$ constant, where the exponent $\mathrm{n}$ can be regarded as an exposure time reinforcement factor.

The value of the exponent $n$ can be used, therefore, to determine whether a toxicant shows effects reinforced by time $(n>1)$ or follows Haber's rule $(n=1)$. Effects reinforced by time are also called time-cumulative effects, as a given dose will produce effects that build up over time of exposure [10]. We have identified cases of time-dependent toxicity where the value of $n$ is well below 1 . Time-dependent effects generally occur when dissociation of bound receptors is a slow process. In the cases where effects are reinforced by time or follow Haber's rule they are explained by irreversible receptor binding, but in the cases of time-dependent toxicity with $n<1$ receptor binding must be assumed to be reversible albeit a

\begin{tabular}{|c|c|c|c|c|c|c|}
\hline $\begin{array}{l}\text { Bound Receptors in } \\
\text { Relation to Toxicant } \\
\text { Concentration }\end{array}$ & $\begin{array}{l}\text { Receptor } \\
\text { Binding }\end{array}$ & Effect & $\begin{array}{l}\text { Effect in Relation } \\
\text { to Bound } \\
\text { Receptors }\end{array}$ & $\begin{array}{c}\text { Effect in Relation } \\
\text { to Toxicant } \\
\text { Concentration }\end{array}$ & Characteristics * & $\begin{array}{c}\text { Value of } \\
\text { Exponent } n\end{array}$ \\
\hline \multirow[b]{2}{*}{$C_{R} \sim C$} & \multirow{2}{*}{$\begin{array}{c}\text { Reversible } \\
T_{R} \rightarrow 0\end{array}$} & Reversible & $E \sim C_{R}$ & $E \sim C$ & Dose-dependent & $\mathrm{n}<1$ \\
\hline & & Irreversible & $E \sim \int C_{R} d t$ & \multirow{2}{*}{$E \sim \int C d t$} & \multirow{2}{*}{$\begin{array}{l}\text { Haber's rule } \\
C \cdot t=\text { constant }\end{array}$} & \multirow{2}{*}{$\mathrm{n}=1$} \\
\hline$C_{R} \sim \int C d t$ & $\begin{array}{l}\text { Irreversible } \\
T_{R} \rightarrow \infty\end{array}$ & Reversible & $E \sim C_{R}$ & & & \\
\hline
\end{tabular}
slow process. In such a situation high exposure levels are probably more effective than low exposure levels. Table 1 offers a synopsis of the types of dose-response that a toxicant may follow.

Table 1. Dose-response characteristics according to Druckrey-Küpfmüller.

$\mathrm{C}_{\mathrm{R}}=$ bound receptors; $\mathrm{C}=$ toxicant concentration; $\mathrm{T}_{\mathrm{R}}=$ time dissociation constant; $\mathrm{E}=$ effect; ${ }^{*}$ the assumption made to explain Haber's rule and time-reinforced toxicity is that $\mathrm{C}$ remains constant upon repeated dosing (continuous exposure). 


\section{How to Identify Chemicals with Time-Dependent Toxicity}

The above theoretical explanation suggests that toxicological data are best understood when the toxic doses of a chemical are referred to specific times of exposure rather than to fixed times, as established in standard toxicity tests (e.g., OECD guidelines). The time-to-effect (TTE) bioassay designed by Newman and McCloskey [27] aims precisely at recording toxic effects over longer periods of time and is suitable for the purpose of analysing time-dependent toxicity of chemicals.

A TTE bioassay requires the same experimental setup as the standard toxicity tests (e.g., range of concentrations, minimum number of individuals and cages, replication) but records the survival or another effect on the organisms over consecutive times (e.g., at 1, 2, 4, 7, 14 and 21 days). Data are tabulated in a matrix for the two variables of interest: chemical concentration (or doses for terrestrial organisms) and time to produce an effect. Consequently, the LC50 or LD50 endpoints can be derived for each one of the times recorded while the time to $50 \%$ effect (T50) can be estimated for each of the concentrations used. As with standard toxicity tests, a suitable range of concentrations should be determined prior to conducting a TTE bioassay to ensure that both the toxicity endpoints and T50s can be calculated. The information obtained from the TTE bioassays is superior to that from standard toxicity tests, as it allows identification of time-dependent toxicity patterns in addition to calculating the dose-dependent endpoints. A good example of this procedure can be found in Simon-Delso et al. 2018 [17].

A simple way to scrutinize time-dependent toxicity of a chemical is to look at the total doses that effectively cause an effect within a certain period. When the total doses to cause an effect do not change significantly during the observation period, then the chemical follows Haber's rule and its toxicity is dependent on both dose and exposure time. However, when the total doses to cause an effect decrease progressively throughout the test period there is proof that the toxicity of the chemical is reinforced by time, i.e., it is time-cumulative. Conversely, when the total doses to cause an effect increase with the exposure time this suggests that although time-dependency may have been observed, the toxicity of low doses is less effective. This could occur when the chemical is metabolised quickly to non-toxic forms by the organism or rapidly eliminated; and the toxicity of the chemical is most effective at high dose. Examples of these three possible cases are presented in Table 2.

Table 2. The three patterns of chemical toxicity with time of exposure as identified by the total dose or $\mathrm{C} \times \mathrm{T} 50$. The carcinogen diethylnitrosamine shows time-cumulative toxicity in rats. The organophosphorus insecticide phosmet shows time-dependent toxicity that complies with Haber's rule. Toxicity of the reagent cadmium chloride is mainly dose-dependent.

\begin{tabular}{|c|c|c|c|c|c|c|c|c|}
\hline \multicolumn{3}{|c|}{ Diethylnitrosamine $^{1}$} & \multicolumn{3}{|l|}{ Phosmet $^{2}$} & \multicolumn{3}{|l|}{$\mathrm{CdCl}_{2}{ }^{3}$} \\
\hline \multicolumn{3}{|l|}{ Rattus sp. } & \multicolumn{3}{|l|}{ Poecilia reticulata } & \multicolumn{3}{|l|}{ Daphnia magna } \\
\hline \multicolumn{3}{|c|}{$\mathrm{n}=2.3, \mathrm{r}^{2}=1.0$} & \multicolumn{3}{|l|}{$\mathrm{n}=1.0, \mathrm{r}^{2}=0.96$} & \multicolumn{3}{|l|}{$\mathrm{n}=0.6, \mathrm{r}^{2}=0.98$} \\
\hline Daily dose & T50 & Total dose & Concentration (C) & T50 & $\mathrm{C} \times \mathrm{T} 50$ & Concentration (C) & T50 & $\mathrm{C} \times \mathrm{T} 50$ \\
\hline $\mathrm{mg} \cdot \mathrm{kg}^{-1}$ & days & $\mathrm{mg} \cdot \mathrm{kg}^{-1}$ & $\mu \mathrm{M}$ & days & $\mu \mathrm{M}$ & $\mu \mathrm{g} \cdot \mathrm{L}^{-1}$ & days & $\mu \mathrm{g} \cdot \mathrm{L}^{-1}$ \\
\hline 9.6 & 101 & 963 & 8 & 1 & 8.0 & 56 & 2 & 105 \\
\hline 4.8 & 137 & 660 & 5.2 & 2 & 10.4 & 32 & 6 & 181 \\
\hline 2.4 & 192 & 460 & 3.2 & 3 & 9.6 & 18 & 11 & 203 \\
\hline 1.2 & 238 & 285 & 2.7 & 4 & 10.8 & 10 & 38 & 375 \\
\hline 0.6 & 355 & 213 & 2.4 & 5 & 12.0 & 5.6 & 58 & 325 \\
\hline 0.3 & 457 & 137 & 1.8 & 6 & 10.8 & 3.2 & $292 *$ & 935 \\
\hline 0.15 & 609 & 91 & 1.6 & 7 & 11.2 & & & \\
\hline \multirow[t]{2}{*}{0.075} & 840 & 64 & 0.93 & 8 & 7.4 & & & \\
\hline & & & 0.8 & 10 & 8.0 & & & \\
\hline
\end{tabular}

$\mathrm{C}=$ concentration in water; T50 = median time to effect. * estimated value greater than the life span of the organism.

${ }^{1}$ Druckrey et al. 1963 [14]; ${ }^{2}$ Legierse et al. 1999 [22]; ${ }^{3}$ Kooijman 1981 [28]. 
Another way to find out the toxic dose-response pattern of a chemical is to fit a regression line to the experimental endpoints, which are usually estimated as median lethal doses (LD50s) or concentrations (LC50s) against the exposure time (or ED50s and EC50s for non-lethal effects).

Most authors who carry out toxicity experiments over long periods do not usually estimate such endpoints but instead indicate the T50 values for each concentration $\mathrm{C}$ or dose tested. In any case, a linear fit is obtained when using logs for the two variables:

$$
\operatorname{LnT} 50=a+b \operatorname{LnC}
$$

The result is the same whether using calculated toxicity endpoints or actual tested concentrations, because the T50 for a given concentration indicates the LC50 or EC50 at that precise time [29].

Equation (7) allows estimation of the exponent $n$, which is calculated as the absolute value of the inverse of the slope in the regression: $n=1 /$ slope|. As described above, values of $n=1$ indicate the chemical is time-dependent and follows Haber's rule. Values of $n>1$ indicate time-cumulative or reinforced toxicity, whereas values of $\mathrm{n}<1$ indicate the toxicity of the chemical is mainly dose-dependent. Examples of the three types of toxicity patterns determined by log-log regressions are shown in Figure 1.

Given the simplicity with which time-dependency can be scrutinized, the above procedures should be readily incorporated in the standard OECD toxicity tests. One obvious hurdle is that most test guidelines refer to fixed timeframes, so researchers are not required to determine the endpoints at other times than those specified in the guidelines. This shortcoming, which prevents identification of time-dependent toxicity, can be easily overcome by extending the current fixed-time tests so they become variable-time tests (i.e., TTE bioassays).

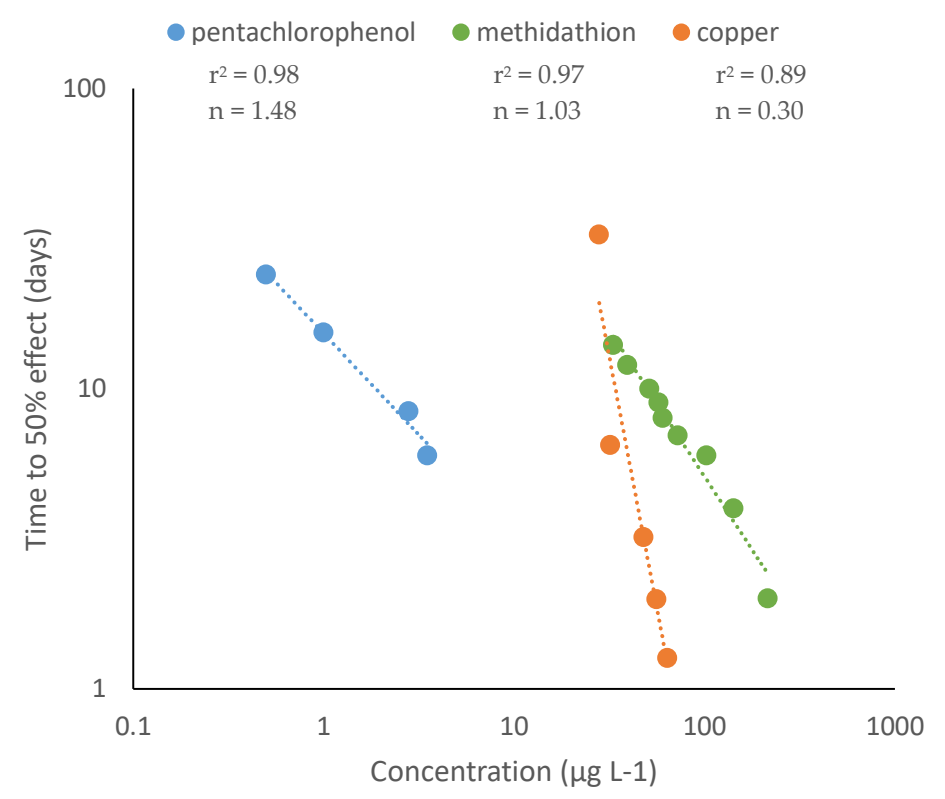

Figure 1. Time-dependent toxicity identified by log-log regression. Time-cumulative toxicity of the biocide pentachlorophenol to the amphipod Gammarus pulex (after Ashauer et al. 2007 [30]). Toxicity of the insecticide methidathion on guppies (Poecilia reticulata) is time-dependent and follows Haber's rule (after Legierse et al. 1999 [22]). The toxicity of copper to Daphnia magna is mainly dose-dependent (after Hoang et al. 2007 [31]).

\section{Experimental Evidence for Neonicotinoids}

Aware of the delayed mortality and chronic effects of neonicotinoids in organisms, some researchers have conducted laboratory experiments aimed at measuring lethal endpoints for neonicotinoids at various times of exposure. Experimental designs differ markedly among researchers and do not always conform to the TTE bioassay described above, but are often sufficient to estimate toxicity 
trends with time. Although not exhaustive, a list of cases where neonicotinoids have shown to have time-cumulative lethality on particular organisms is discussed below. The original data reported by the various authors comprise either LC50 values for variable times or T50 values for individual concentrations, which allowed us to perform a regression between both parameters, as in Figure 1.

Terrestrial and aquatic organisms are treated separately because the exposures are different. Terrestrial organisms are fed regularly on food laced with the chemical being tested, so the total dose that produces an effect is calculated multiplying the concentration of the treatment by the amount of food ingested daily and/or for the entire duration of the bioassay. Aquatic organisms are immersed in solutions spiked with known concentrations of the chemical being tested. The actual doses taken up by the organisms are unknown, as they depend on variable uptake through the epidermis, gills and ingested food (chronic experiments require regular feeding). However, as the internal doses are proportional to the external concentrations of chemical in the media, the effects can be related directly to such concentrations.

\subsection{Aquatic Organisms}

Information for 36 tests and four different neonicotinoid compounds was analysed, and the results are shown in Table 3. The data collected refers to eight species of aquatic insects belonging to four different taxa, plus five species of crustaceans from four taxa and one molluscan species. All species tested are freshwater organisms, as the scarce information available on estuarine and marine organisms refers only to acute toxicity and did not allow analysis of time-dependent toxicity [32]. 
Table 3. Time-cumulative toxicity of neonicotinoids in aquatic organisms.

\begin{tabular}{|c|c|c|c|c|c|c|c|c|c|c|}
\hline \multirow{2}{*}{ Taxa } & \multirow{2}{*}{ Species } & \multirow{2}{*}{ Chemical } & \multirow{2}{*}{ n (1/slope) } & \multicolumn{3}{|c|}{ Regression Parameters } & \multirow{2}{*}{$\Delta \mathrm{LC}_{50}$} & \multirow{2}{*}{ No. $c$ tested } & \multirow{2}{*}{$\begin{array}{c}\text { Exposure } \\
\text { Time (days) }\end{array}$} & \multirow{2}{*}{ Reference } \\
\hline & & & & Intercept & Slope & $r^{2}$ & & & & \\
\hline Diptera & Aedes aegypti & CLO & 1.70 & 3.835 & -0.588 & 0.98 & 7 & 5 & 3 & Ahmed and Matsumura 2012 [33] \\
\hline Diptera & Chironomus dilutus & CLO & 3.11 & 2.922 & -0.322 & 1.0 & 9 & 5 & 40 & Cavallaro et al. 2017 [34] \\
\hline Ephemeroptera & Deleatidium $s p$ & CLO & 1.59 & 3.515 & -0.628 & 1.0 & 3 & 10 & 28 & Macaulay et al. 2019 [35] \\
\hline Amphipoda & Hyalella azteca & IMI & 1.58 & 4.085 & -0.634 & 0.65 & 8 & 5 & 28 & Stoughton et a. 2008 [36] \\
\hline Cladocera & Daphnia magna & IMI & 2.41 & 6.540 & -0.410 & 0.89 & 5 & 6 & 10 & Sanchez-Bayo 2009 [29] \\
\hline Cladocera & Daphnia magna & IMI & 1.91 & 6.646 & -0.523 & 0.99 & 21 & 6 & 4 & Sanchez-Bayo (unpublished) \\
\hline Cladocera & Daphnia magna & IMI & 2.56 & 5.999 & -0.390 & 0.99 & na & 6 & 21 & Ieromina et al. 2014 [37] \\
\hline Diptera & Aedes aegypti & IMI & 2.90 & 2.771 & -0.345 & 0.99 & 23 & 5 & 3 & Ahmed and Matsumura 2012 [33] \\
\hline Diptera & Chaoborus obscuripes & IMI & 1.62 & 4.897 & -0.618 & 1.0 & 23 & 5 & 28 & Roessink et al. 2013 [38] \\
\hline Diptera & Chironomus dilutus & IMI & 1.21 & 3.254 & -0.825 & 1.0 & na & 5 & 28 & Stoughton et al 2008 [36] \\
\hline Diptera & Chironomus dilutus & IMI & 1.30 & 2.962 & -0.772 & 1.0 & na & 5 & 40 & Cavallaro et al. 2017 [34] \\
\hline Ephemeroptera & Cloeon dipterum & IMI & 2.52 & 2.684 & -0.397 & 1.0 & 135 & 5 & 28 & Roessink et al. 2013 [38] \\
\hline Ephemeroptera & Cloeon dipterum & IMI & $2.40 *$ & 2.634 & -0.416 & 0.96 & 700 & 7 & 28 & Van den Brink et al. 2016 [39] \\
\hline Ephemeroptera & Cloeon dipterum & IMI & 2.03 & 3.137 & -0.493 & 0.84 & 13 & 7 & 4 & Van den Brink et al. 2016 [39] \\
\hline Ephemeroptera & Cloeon dipterum & IMI & 1.79 & 2.531 & -0.559 & 0.92 & 8 & 7 & 28 & Van den Brink et al. 2016 [39] \\
\hline Ephemeroptera & Cloeon dipterum & IMI & $2.11 *$ & 3.037 & -0.473 & 0.80 & 187 & 7 & 28 & Van den Brink et al. 2016 [39] \\
\hline Ephemeroptera & Cloeon dipterum & IMI & 1.38 & 3.862 & -0.726 & 0.99 & 7 & 7 & 4 & Van den Brink et al. 2016 [39] \\
\hline Ephemeroptera & Coenis horaria & IMI & 1.57 & 2.597 & -0.638 & 1.0 & 21 & 5 & 28 & Roessink et al. 2013 [38] \\
\hline Ephemeroptera & Deleatidium $s p$ & IMI & 2.05 & 2.620 & -0.489 & 0.95 & 14 & 10 & 28 & Macaulay et al. 2019 [35] \\
\hline Isopoda & Asellus aquaticus & IMI & 1.41 & 5.466 & -0.709 & 1.0 & 16 & 5 & 28 & Roessink et al. 2013 [38] \\
\hline Megaloptera & Sialis lutaria & IMI & 2.94 & 4.515 & -0.340 & 1.0 & 308 & 5 & 28 & Roessink et al. 2013 [38] \\
\hline Ostracoda & Cypridopsis vidua & IMI & 4.67 & 5.110 & -0.210 & 0.88 & na & 6 & 4 & Sanchez-Bayo 2009 [29] \\
\hline Amphipoda & Gammarus pulex & THC & 1.30 & 1.729 & -0.767 & 0.72 & na & 5 & 15 & Beketov \& Liess 2008 [9] \\
\hline Diptera & Aedes aegypti & THC & 1.54 & 4.166 & -0.648 & 1.0 & 5 & 5 & 3 & Ahmed and Matsumura 2012 [33] \\
\hline Ephemeroptera & Cloeon dipterum & THC & $2.23 *$ & 2.707 & -0.449 & 0.96 & 557 & 7 & 28 & Van den Brink et al. 2016 [39] \\
\hline Ephemeroptera & Cloeon dipterum & $\mathrm{THC}^{* *}$ & $1.83 *$ & 2.353 & -0.547 & 0.95 & 190 & 7 & 28 & Van den Brink et al. 2016 [39] \\
\hline
\end{tabular}


Table 3. Cont.

\begin{tabular}{|c|c|c|c|c|c|c|c|c|c|c|}
\hline \multirow{2}{*}{ Taxa } & \multirow{2}{*}{ Species } & \multirow{2}{*}{ Chemical } & \multirow{2}{*}{ n (1/slope) } & \multicolumn{3}{|c|}{ Regression Parameters } & \multirow{2}{*}{$\Delta \mathrm{LC}_{50}$} & \multirow{2}{*}{ No. $\mathrm{c}$ tested } & \multirow{2}{*}{$\begin{array}{l}\text { Exposure } \\
\text { Time (days) }\end{array}$} & \multirow{2}{*}{ Reference } \\
\hline & & & & Intercept & Slope & $\mathbf{r}^{2}$ & & & & \\
\hline Ephemeroptera & Cloeon dipterum & THC & 1.25 & 2.398 & -0.798 & 0.98 & na & 7 & 28 & Van den Brink et al. 2016 [39] \\
\hline Ephemeroptera & Cloeon dipterum & THC & 1.25 & 3.166 & -0.801 & 0.97 & 6 & 7 & 4 & Van den Brink et al. 2016 [39] \\
\hline Ephemeroptera & Cloeon dipterum & THC & 1.26 & 4.242 & -0.797 & 0.89 & 6 & 7 & 4 & Van den Brink et al. 2016 [39] \\
\hline Isopoda & Asellus aquaticus & THC & 1.25 & 0.932 & -0.802 & 0.94 & na & 3 & 19 & Beketov \& Liess 2008 [9] \\
\hline Odonata & Sympetrum striolatum & THC & 1.53 & 7.430 & -0.650 & 1.0 & na & 4 & 11 & Beketov \& Liess 2008 [9] \\
\hline Amphipoda & Gammarus kischineffensis & TMX & 2.41 & 4.768 & -0.416 & 1.0 & 28 & 6 & 4 & Ugurlu et al. 2015 [40] \\
\hline Diptera & Chironomus dilutus & TMX & 2.51 & 3.896 & -0.398 & 1.0 & na & 5 & 40 & Cavallaro et al. 2017 [34] \\
\hline Ephemeroptera & Cloeon dipterum & TMX & $2.05 *$ & 2.980 & -0.487 & 0.91 & 163 & 7 & 28 & Van den Brink et al. 2016 [39] \\
\hline Ephemeroptera & Cloeon dipterum & TMX ** & $1.70 *$ & 2.949 & -0.589 & 0.96 & 131 & 7 & 28 & Van den Brink et al. 2016 [39] \\
\hline Mollusca & Planorbella pilsbryi & TMX & 1.33 & 8.521 & -0.753 & 1.0 & 6 & 5 & 28 & Prosser et al. 2016 [41] \\
\hline
\end{tabular}

${ }^{*}$ Combined data from acute and chronic tests; ${ }^{* *} \mathrm{EC} 50$ data; $\Delta \mathrm{LC}_{50}=$ difference between short- and long-term LC50s; na = not available, as T50 was estimated. CLO $=$ clothianidin; IMI = imidacloprid; THC $=$ thiacloprid; TMX $=$ thiamethoxam . 
In all cases, the species tested showed time-cumulative toxicity, as indicated by values of the exponent $n>1$. Typical values of $n$ range between 1.2 and 2.5, with only three cases in which $n$ is higher: 2.9 for imidacloprid on Aedes aegypti [33], 3.1 for clothianidin on Chironomus dilutus [34] and 4.7 for imidacloprid on Cypridopsis vidua [29]. The regression coefficients $\left(\mathrm{r}^{2}\right)$ obtained in all cases are $>0.80$ except for the amphipod Gammarus pulex exposed to thiacloprid, which is 0.72 . Values of $r^{2}=$ 1.0 are obtained when comparing only two LC50 values because the authors did not report LC50s for intermediate times within the entire exposure period.

It is noted that the decrease in LC50 values ( $\triangle \mathrm{LC} 50)$ between the initial and final exposure times varies markedly. Differences are smaller for clothianidin (3 to 9 times) and larger for imidacloprid and thiamethoxam (5 to 28 times), regardless of the length of the exposure period. While the sensitivity among species is obviously different, the largest $\triangle \mathrm{LC} 50$ values are obtained when comparing acute and chronic LC50s determined in split experiments (Figure 2a-c). For example, van den Brink et al. 2016 carried out sets of acute toxicity tests with nymphs of the mayfly Cloeon dipterum using a range of concentrations and determined the LC50s for 1, 2, 3 and 4 days. They also carried out another set of chronic toxicity tests using a lower range of concentrations and determined the LC50s for 7, 14, 21 and 28 days. When comparing the $1-\mathrm{d}$ LC50 values to the $28-\mathrm{d}$ LC50 values, the $\triangle \mathrm{LC} 50$ are $187-700$ for imidacloprid, 190-557 for thiacloprid and 131-163 for thiamethoxam. In the case of imidacloprid, the largest difference corresponds to tests carried out in the spring-summer season (April-August) and the lowest to those performed in autumn (October-December). For thiacloprid and thiamethoxam, the largest value refers to LC50 endpoints and the lowest to EC50 endpoints [39]. Note also that whenever the T50 only was reported, no $\triangle \mathrm{LC} 50$ could be determined.

It should also be noted that six additional tests carried out by van den Brink et al. 2016 with the mayfly nymphs followed Haber's rule. Two of them used imidacloprid and the others thiamethoxam; data from another test could not be used (Table S1). The same finding applies to two tests using imidacloprid: one on the amphipod Gammarus pulex [38] and another on the midge Chironomus riparius [42]. A further test using thiacloprid on the caddisfly Notidobia ciliaris suggests the same pattern, as indicated by $n=0.91$ despite the poor fit of the model to the data $\left(r^{2}=0.47\right)$ [9].

We emphasize that testing conditions are important for an accurate determination of LC50 or T50 values, which in turn can influence the calculation of $\mathrm{n}$ values in the model regression. For example, acute tests (4 days) with thiamethoxam on the amphipod Gammarus kischineffensis showed a clear time-cumulative pattern $(n=2.41)$ due to the excellent fit to the estimated LC50 values $\left(r^{2}=1.0\right)[40]$, whereas the same compound tested on the same species under different conditions showed $n=0.80$, which is close to following Haber's rule [43]. The latter test, however, showed poorer goodness of fit to the data $\left(r^{2}=0.87\right)$ than the former one.

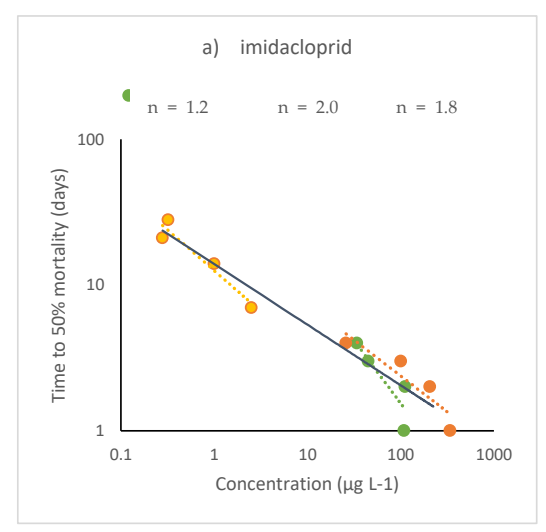

Figure 2. Cont. 


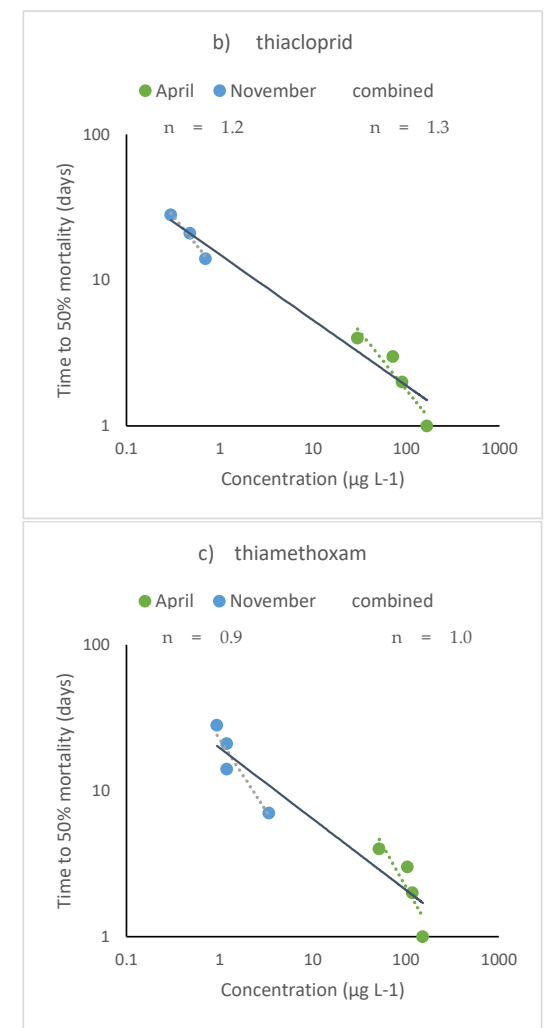

Figure 2. Time-cumulative toxicity of (a) imidacloprid, (b) thiacloprid and (c) thiamethoxam tested on nymphs of the mayfly Cloeon dipterum (after van den Brink et al. 2016 [39]). Tests were carried out separately for acute (up to 4 days) and chronic toxicity (up to 28 days), with individual tests showing values of $n \geq 1$ (dotted lines). The combined sets also show values of $n>1$ (solid lines), confirming the time-dependent toxicity of all three compounds.

\subsection{Terrestrial Organisms}

Information for 27 tests and four different neonicotinoid compounds was analysed, and the results are shown in Table 4 . The data collected refers to 14 species of insects belonging to seven different taxonomic orders; among them is the brown planthopper (Nilaparvata lugens), a pest of rice crops and Frankiniella occidentalis, a pest of many flowers. In addition to the above, two tests using clothianidin showed that this compound followed Haber's rule when tested on honeybees (Apis mellifera) [44,45], whereas the same compound tested on bumblebees (Bombus terrestris) and mason bees (Osmia bicornis) appeared to show mainly dose-dependent toxicity [45]. One additional data set included acetamiprid, but this compound did not show time-dependent toxicity when tested on honeybees [46] (Table S2), perhaps because it is quickly metabolised [47]. 
Table 4. Time-cumulative toxicity of neonicotinoids in terrestrial organisms.

\begin{tabular}{|c|c|c|c|c|c|c|c|c|c|c|c|}
\hline \multirow{2}{*}{ Taxa } & \multirow{2}{*}{ Species } & \multirow{2}{*}{ Comments } & \multirow{2}{*}{ Chemical } & \multirow{2}{*}{ n (1/slope) } & \multicolumn{3}{|c|}{ Regression Parameters } & \multirow{2}{*}{$\Delta \mathrm{LC}_{50}$} & \multirow{2}{*}{ No. $\mathrm{c}$ tested } & \multirow{2}{*}{ Exposure Time (days) } & \multirow{2}{*}{ Reference } \\
\hline & & & & & Intercept & Slope & $\mathbf{R}^{2}$ & & & & \\
\hline Hemiptera & Cyrtorhinus lividipennis & & CLO & 3.74 & 1.173 & -0.268 & 1.0 & 13 & 6 & 2 & Preetha et al. 2010 [48] \\
\hline Hemiptera & Nilaparvata lugens & & CLO & 4.49 & 1.885 & -0.233 & 1.0 & 22 & 6 & 2 & Preetha et al. 2010 [48] \\
\hline Hymenoptera & Apis mellifera & & CLO & 1.19 & 2.538 & -0.841 & 0.94 & 11 & 6 & 3 & Laurino et al. 2011 [46] \\
\hline Hymenoptera & Apis mellifera & & CLO & 1.62 & 3.980 & -0.617 & 1.0 & 14 & 8 & 10 & Alkassab \& Kirchner 2016 [49] \\
\hline Coleoptera & Strategus aloeus & Adults & IMI & 2.29 & 2.073 & -0.437 & 1.0 & $\mathrm{Na}$ & 7 & 3 & Martinez et al. 2014 [50] \\
\hline Diptera & Drosophila melanogaster & Males & IMI & 1.42 & 8.654 & -0.703 & 1.0 & 29 & 10 & 8 & Charpentier et al. 2014 [51] \\
\hline Diptera & Drosophila melanogaster & Females & IMI & 2.18 & 5.957 & -0.460 & 1.0 & 172 & 10 & 8 & Charpentier et al. 2014 [51] \\
\hline Diptera & Drosophila melanogaster & Larvae & IMI & 1.67 & 6.052 & -0.598 & 1.0 & 52 & 10 & 8 & Charpentier et al. 2014 [51] \\
\hline Hemiptera & Cyrtorhinus lividipennis & & IMI & 1.50 & 4.811 & -0.665 & 1.0 & 3 & 6 & 2 & Preetha et al. 2010 [48] \\
\hline Hymenoptera & Aphidius colemani & Adults & IMI & 2.29 & 3.540 & -0.437 & 0.59 & na & 6 & 8 & D'Avila et al. 2018 [52] \\
\hline Hymenoptera & Apis florea & & IMI & 2.74 & 1.177 & -0.365 & 0.98 & na & 5 & 2 & Husain et al. 2014 [53] \\
\hline Hymenoptera & Apis dorsata & & IMI & 2.60 & 1.454 & -0.384 & 0.99 & na & 5 & 2 & Husain et al. 2014 [53] \\
\hline Hymenoptera & Apis mellifera & & IMI & 2.41 & 1.190 & -0.416 & 0.91 & na & 5 & 2 & Husain et al. 2014 [53] \\
\hline Hymenoptera & Apis mellifera & & IMI & 5.83 & 5.190 & -0.170 & 0.85 & na & 5 & 10 & Suchail et al. 2001 [54] \\
\hline Hymenoptera & Apis mellifera & & IMI & 2.67 & 4.836 & -0.375 & 0.94 & 46 & 5 & 10 & DEFRA 2007 [55] \\
\hline Hymenoptera & Bracon hebetor & Adults & IMI & 1.80 & 2.387 & -0.554 & 1.0 & 3 & 3 & 2 & Preetha et al. 2010 [56] \\
\hline Hymenoptera & Chelonus blackburnii & Adults & IMI & 1.51 & 5.377 & -0.662 & 0.99 & 7 & 3 & 1 & Preetha et al. 2010 [56] \\
\hline Hymenoptera & Haeckeliania sperata & & IMI & 1.52 & -1.039 & -0.656 & 0.92 & na & 5 & 2 & Carrillo et al. 2009 [57] \\
\hline Hymenoptera & Linepithema humile & & IMI & 3.47 & 0.476 & -0.288 & 0.69 & na & 4 & 14 & Rust et al. 2004 [58] \\
\hline Isoptera & Reticulitermes flavipes & Sand & IMI & 1.89 & 3.125 & -0.528 & 0.95 & 1167 & 5 & 21 & Ramakrishnan et al. 2000 [59] \\
\hline Isoptera & Reticulitermes flavipes & Sandy loam & IMI & 2.65 & 3.773 & -0.378 & 0.89 & 14 & 7 & 21 & Ramakrishnan et al. 2000 [59] \\
\hline Isoptera & Reticulitermes flavipes & Silty clay loam & IMI & 4.00 & 3.247 & -0.250 & 0.83 & 3126 & 7 & 21 & Ramakrishnan et al. 2000 [59] \\
\hline Thysanoptera & Frankiniella occidentalis & Larvae & IMI & 1.97 & 0.495 & -0.508 & 0.92 & na & 5 & 8 & Niassy et al. 2012 [60] \\
\hline Hymenoptera & Apis mellifera & & THC & 2.10 & 1.838 & -0.477 & 0.44 & 23 & 3 & 3 & Laurino et al. 2011 [46] \\
\hline Hymenoptera & Apis mellifera & & TMX & 2.21 & 4.040 & -0.452 & 0.95 & na & 3 & 18 & Oliveira et al. 2014 [61] \\
\hline Hymenoptera & Linepithema humile & & TMX & 1.55 & -5.538 & -0.643 & 0.73 & na & 4 & 14 & Rust et al. 2004 [58] \\
\hline Thysanoptera & Frankiniella occidentalis & Larvae & TMX & 1.55 & -0.075 & -0.645 & 0.98 & na & 5 & 8 & Niassy et al. 2012 [60] \\
\hline
\end{tabular}

$\Delta \mathrm{LC}_{50}=$ difference between short- and long-term LC50s; na = not available, as T50 were estimated instead. $\mathrm{CLO}=$ clothianidin; IMI = imidacloprid; THC = thiacloprid; $\mathrm{TMX}=$ thiamethoxam. 
Typical values of $\mathrm{n}$ obtained from tests with terrestrial insects range between 1.2 and 2.7 , similar to that with aquatic organisms. However, five tests showed higher values of the $\mathrm{n}$ exponent: clothianidin on the predatory bug Cyrtorhinus lividipennis and the brown hopper pest species indicate values of $\mathrm{n}=3.7$ and 4.5, respectively [48]; imidacloprid on the ant Linepithema humile $(\mathrm{n}=3.5)$ [58], on the termite Reticulitermes flavipes $(n=4.0)$ [59] and on the honeybee $(n=5.8)$ [54]. The latter value of $n$ is unusually high, suggesting that the bees tested may have died by an interaction of the insecticide with other factors such as pathogenic infections or others. Nevertheless, given the good fit of the model to the dataset $\left(r^{2}=0.85\right)$ this result cannot be excluded. Examples of time-cumulative toxicity for three chemicals are shown in Figure 3a,b.
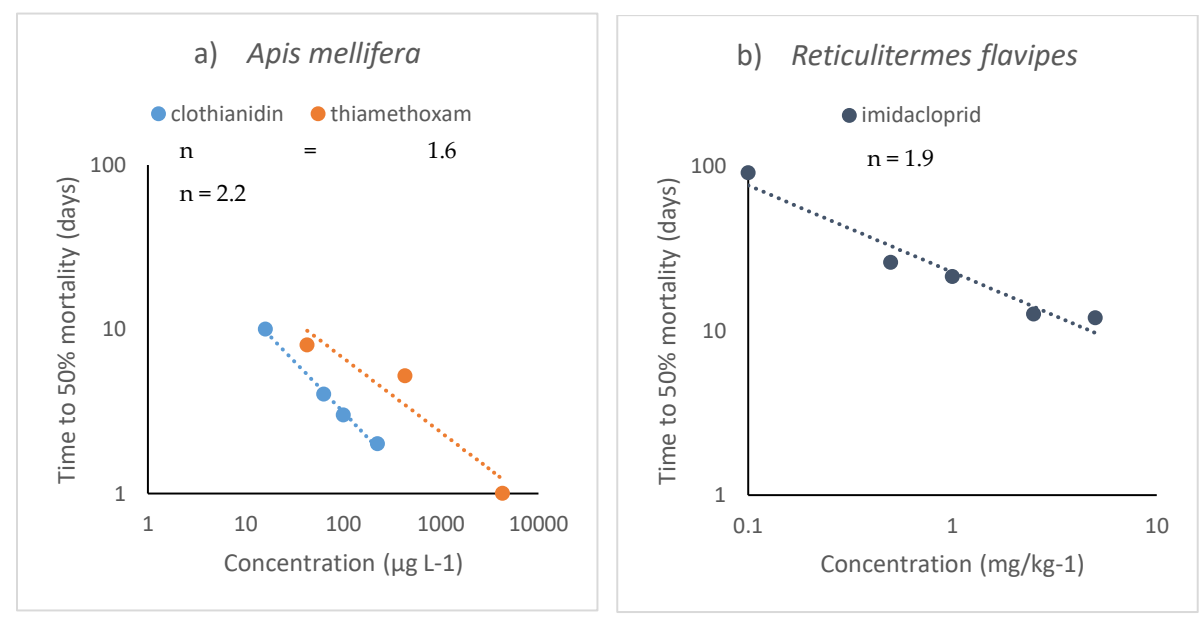

Figure 3. Examples of time-cumulative toxicity in terrestrial insects for (a) clothianidin and thiamethoxam on honey bees (Apis mellifera) [49,61]; (b) imidacloprid on termites Reticulitermes flavipes (sandy soil) [59].

The decrease in LC50 values ( $\triangle \mathrm{LC} 50)$ between the initial and final exposure times varies in the range 3 to 52 for all compounds, with notable exceptions for imidacloprid tested on female fruit flies (Drosophila melanogaster) and termites, which showed differences of 172 times over 8 days and 1167-3126 times over 21 days, respectively [51,59]. The result for imidacloprid on the fruit flies contrasts with previous tests that showed no time-dependent toxicity of this compound to the same species and equal 8-day testing period [62].

We observe that the length of the testing period does not prevent estimation of the $\mathrm{n}$ values provided that the calculated LC50 or T50 values are accurate and show small variance. Conversely, a high variability in the dataset may result in poor fitting of the endpoint values to the regression model and therefore lead to unreliable conclusions. Two of the tests shown in Table 4 fall in the latter category: thiacloprid tested on honeybees [46] showed a time-cumulative pattern $(n=2.1)$ but poor goodness of fit $\left(\mathrm{r}^{2}=0.44\right)$, and imidacloprid tested on adults of the parasitoid Aphidius colemani [52] showed also a time-cumulative pattern $(n=2.3)$ despite the poor fit $\left(r^{2}=0.59\right)$. In both cases the patterns of toxicity may be regarded as unreliable, even if they are time-dependent.

\section{Implications for Risk Assessment of Neonicotinoids}

Research on the influence of time on the toxicity of pesticides spans several decades [28,30,63], and yet most ecotoxicologists do not consider the time factor in their routine toxicity tests. The fact that OECD toxicity test guidelines stipulate fixed times of exposure for both acute and chronic tests is a major hurdle, as chemical regulators only take into consideration toxicity data that conform with such tests. As a result of having insufficient toxicological data, environmental risk assessments are often unable to evaluate the real impacts that chemicals have on organisms [64]. This has become apparent in the case of neonicotinoid compounds, for which the current evidence demonstrates their 
actual environmental impacts on both aquatic and terrestrial ecosystems are larger than previously estimated $[65,66]$.

When neonicotinoids were first approved as agricultural insecticides, the only toxicity data available were acute endpoints for a limited number of surrogate terrestrial and aquatic species, as required by the regulators. It was later found that the species indicative of risks to the aquatic environment (i.e., Daphnia sp.) was unusually tolerant to this class of chemicals [67,68], thus making the assessment of impacts on aquatic organisms completely misleading and not representative of the risks posed to the majority of aquatic invertebrates [69]. Further research on aquatic invertebrates revealed a delayed effect on mortality, especially among aquatic insect species [9] that could not be detected in standard acute tests. In addition to the lethal effects, a plethora of negative sublethal effects on bees as well as in vertebrates [70,71] demonstrate that risk assessments for neonicotinoids have been inadequate to protect the environment.

However, the main deficiency in the risk assessments of neonicotinoids was and still is the consideration of acute endpoint values while ignoring delayed and chronic effects. This should not surprise us, as the time-cumulative toxicity of these compounds was unknown and could not be imagined. This unfortunate situation has now changed. As demonstrated by the evidence shown in Tables 3 and 4, the toxicity of neonicotinoids is reinforced by time and fit the pattern of toxicity explained by Druckrey-Küpfmüller [19]. This feature explains their slowness in producing toxic effects, as they are delayed, with their acute toxicity endpoints being relatively high in comparison to those of organophosphorus and pyrethroid compounds. It also explains the discrepancy in toxicity endpoints for bees reported in the literature (up to 33-fold), as different authors used different exposure times to estimate them [72]. Thus, values of lethal endpoints decrease markedly between short and long exposures [38], a fact than many researchers could not explain nor understand properly.

The main implication is that the risks to pollinators and other beneficial non-target arthropods such as predatory insects and parasitic wasps have been underestimated. Constant exposure to neonicotinoid residues in pollen and nectar leads to the eventual death of the forager bees, moths, butterflies and polyphagous parasitoids [73] even if their losses cannot be adequately monitored because the dead insects cannot be found [74]. Most importantly, the toxicity to parasitoids is usually higher than that to the pest species they control [48], which inevitably results in the loss of the natural pest control in agroecosystems. For this reason, neonicotinoids are not compatible with integrated pest management (IPM) approaches in agriculture [75,76], despite claims to the contrary made in studies that only looked at the acute toxicity in standard glass plate tests $[77,78]$. If we are to protect the biodiversity of beneficial arthropods, which are more efficient in controlling pests than chemicals, neonicotinoids have no place in sustainable agriculture [79], as they undermine the natural pest control systems.

In aquatic ecosystems, neonicotinoids eliminate the nymphs and other insect larvae that are inevitably exposed to low albeit constant concentrations of these compounds. Previous risk assessments based on acute toxicity endpoints could not find significant risks $[80,81]$ because they ignored the subtle and delayed mortality that takes place as a result of the time-cumulative pattern of toxicity of neonicotinoids. No matter how low their waterborne residues maybe, sensitive species such as caddisflies, mayflies, stoneflies, craneflies and others experience cumulative death tolls that make the recovery of their populations unlikely if not impossible (unless there is re-colonisation from outside sources). Not only insects, but planktonic and benthic crustaceans undergo the same fate and are decimated [82], to the extent that fish populations starve and collapse in turn [83]. As a result, the diverse arthropod communities of freshwater ecosystems collapse, impairing the recycling of nutrients and causing starvation among many insectivorous birds, reptiles and amphibians that depend on them [65].

Time-cumulative toxicity of neonicotinoids is repeatedly found among aquatic and terrestrial species of invertebrates alike [84], perhaps because the most common subtype of nAChRs in these organisms is $\alpha 4 \beta 2$, which shows the strongest binding affinity towards neonicotinoids [5]. As with 
vertebrates, it is conceivable that in the least sensitive organisms, such as waterfleas, the nAChR subunits may be different and have little affinity for these chemicals, since metabolism of neonicotinoids appears to be mediated by mono-oxygenase enzymes of the P450 family in all cases [5].

To protect the environment from further chemical impacts, a new framework for risk assessment of chemicals should consider the time-dependent toxicity in the first tier of the assessment [85]. This is particularly urgent for neonicotinoids and other pesticides with irreversible binding to specific receptors, because they are the most likely candidates to undergo toxic effects that are enhanced by time of exposure.

As neonicotinoids have replaced older pesticide chemistries in most countries, the actual toxic loads of insecticides per area have dramatically increased in recent years [86,87]. It is not surprising, therefore, that current declines of biodiversity have been linked to pesticides in both terrestrial [88] and aquatic environments [89-91], among which neonicotinoids are prevalent. Thus, the decline of dragonfly populations in Japan, particularly the most common species of rice paddies, akiakane (Sympetrum frequens), is attributed to the use of imidacloprid and fipronil over the past 25 years [92]. Also in Japan, the collapse of fisheries in lake Shinji has being linked to the indirect impact of neonicotinoids used in nearby rice farms [83]. In the Netherlands, the decline of macro-invertebrates in surface waters correlates with residues of imidacloprid among other chemicals [82], and imidacloprid is the main factor behind the decline of insectivorous and granivores songbirds in that country [93].

The above are examples adding to the mounting evidence that current risk assessments for registration of chemicals in OECD countries are inadequate to protect biodiversity and ecosystems and need a revamp [94-96]. To provide more realistic risk assessments of agricultural and other chemicals, toxicological bioassays designed for detecting the time-cumulative toxicity of substances should be made mandatory $[17,85]$. Only then we would be able to distinguish chemicals that have time-cumulative and other time-dependent toxicity from those that are mainly dose-dependent.

Supplementary Materials: The following are available online at http://www.mdpi.com/1660-4601/17/5/1629/s1, Table S1: Other time-dependent toxicity of neonicotinoids in aquatic organisms, Table S2: Other time-dependent toxicity of neonicotinoids in terrestrial organisms.

Author Contributions: Conceptualization, data gathering and analysis, writing-original draft preparation, F.S.-B.; writing - review and editing, H.A.T. All authors have read and agreed to the published version of the manuscript.

Acknowledgments: We are grateful to Paul J. van den Brink for allowing us access to his experimental dataset.

Conflicts of Interest: The authors declare no conflict of interest.

\section{References}

1. Simon-Delso, N.; Amaral-Rogers, V.; Belzunces, L.P.; Bonmatin, J.M.; Chagnon, M.; Downs, C.; Furlan, L.; Gibbons, D.W.; Giorio, C.; Girolami, V.; et al. Systemic insecticides (neonicotinoids and fipronil): Trends, uses, mode of action and metabolites. Environ. Sci. Pollut. Res. 2015, 22, 5-34. [CrossRef] [PubMed]

2. Jeschke, P.; Nauen, R.; Schindler, M.; Elbert, A. Overview of the status and global strategy for neonicotinoids. J. Agric. Food Chem. 2011, 59, 2897-2908. [CrossRef] [PubMed]

3. Jeschke, P.; Nauen, R. Neonicotinoids-From zero to hero in insecticide chemistry. Pest Manag. Sci. 2008, 64, 1084-1098. [CrossRef] [PubMed]

4. Hladik, M.L.; Main, A.R.; Goulson, D. Environmental risks and challenges associated with neonicotinoid insecticides. Environ. Sci. Technol. 2018, 52, 3329-3335. [CrossRef] [PubMed]

5. Matsuda, K.; Ihara, M.; Sattelle, D.B. Neonicotinoid insecticides: Molecular targets, resistance, and toxicity. Annu. Rev. Pharmacol. Toxicol. 2020, 60, 241-255. [CrossRef]

6. Tomizawa, M.; Lee, D.L.; Casida, J.E. Neonicotinoid insecticides: Molecular features conferring selectivity for insect versus mammalian nicotinic receptors. J. Agric. Food Chem. 2000, 48, 6016-6024. [CrossRef]

7. Mehlhorn, H.; Mencke, N.; Hansen, O. Effects of imidacloprid on adult and larval stages of the flea Ctenocephalides felis after in vivo and in vitro application: A light- and electron-microscopy study. Parasitol. Res. 1999, 85, 625-637. [CrossRef] 
8. Nauen, R. Behaviour modifying effects of low systemic concentrations of imidacloprid on Myzus persicae with special reference to an antifeeding response. Pestic. Sci. 1995, 44, 145-153. [CrossRef]

9. Beketov, M.A.; Liess, M. Acute and delayed effects of the neonicotinoid insecticide thiacloprid on seven freshwater arthropods. Environ. Toxicol. Chem. 2008, 27, 461-470. [CrossRef]

10. Tennekes, H.A.; Sánchez-Bayo, F. The molecular basis of simple relationships between exposure concentration and toxic effects with time. Toxicology 2013, 309, 39-51. [CrossRef]

11. Rondeau, G.; Sánchez-Bayo, F.; Tennekes, H.A.; Decourtye, A.; Ramírez-Romero, R.; Desneux, N. Delayed and time-cumulative toxicity of imidacloprid in bees, ants and termites. Sci. Rep. 2014, 4, 5566. [CrossRef] [PubMed]

12. Tennekes, H.A.; Sánchez-Bayo, F. Time-dependent toxicity of neonicotinoids and other toxicants: Implications for a new approach to risk assessment. J. Environ. Anal. Toxicol. 2012, S4, S4-001. [CrossRef]

13. Druckrey, H. Quantitative Grundlagen der Krebserzeugung. Klinische Wochenschriften 1943, 22, 532. [CrossRef]

14. Druckrey, H.; Schildbach, A.; Schmaehl, D.; Preussmann, R.; Ivankovic, S. Quantitative analysis of the carcinogenic effect of diethylnitrosamine. Arzneimittelforschung 1963, 13, 841-851.

15. Druckrey, H.; Schagen, B.; Ivankovic, S. Induction of neurogenic malignancies by one single dose of ethyl-nitrosourea (ENU) given to newborn and juvenile BD IX-strain rats. Z. Krebsforsch 1970, 74, 141-161. [CrossRef]

16. Rattner, B.A.; Horak, K.E.; Warner, S.E.; Day, D.D.; Meteyer, C.U.; Volker, S.F.; Eisemann, J.D.; Johnston, J.J. Acute toxicity, histopathology, and coagulopathy in American kestrels (Falco sparverius) following administration of the rodenticide diphacinone. Environ. Toxicol. Chem. 2011, 30, 1213-1222. [CrossRef]

17. Simon-Delso, N.; Martin, G.S.; Bruneau, E.; Hautier, L. Time-to-death approach to reveal chronic and cumulative toxicity of a fungicide for honeybees not revealed with the standard ten-day test. Sci. Rep. 2018, 8, 7241. [CrossRef]

18. Pletz, J.; Sánchez-Bayo, F.; Tennekes, H.A. Dose-response analysis indicating time-dependent neurotoxicity caused by organic and inorganic mercury-Implications for toxic effects in the developing brain. Toxicology 2016, 347, 1-5. [CrossRef]

19. Tennekes, H.A. The significance of the Druckrey-Küpfmüller equation for risk assessment-The toxicity of neonicotinoid insecticides to arthropods is reinforced by exposure time. Toxicology 2010, 276, 1-4. [CrossRef]

20. Walker, C.H.; Hopkin, S.P.; Sibly, R.M.; Peakall, D.B. Principles of Ecotoxicology, 2nd ed.; Taylor \& Francis: Glasgow, UK, 2001; p. 309.

21. Jager, T.; Klok, C. Extrapolating toxic effects on individuals to the population level: The role of dynamic energy budgets. Phil. Trans. R. Soc. London B 2010, 365, 3531-3540. [CrossRef]

22. Legierse, K.C.H.M.; Verhaar, H.J.M.; Vaes, W.H.J.; Bruijn, J.H.M.d.; Hermens, J.L.M. Analysis of the time-dependent acute aquatic toxicity of organophosphorus pesticides: The critical target occupation model. Environ. Sci. Technol. 1999, 33, 917-925. [CrossRef]

23. Jager, T.; Kooijman, S.A.L.M. Modeling receptor kinetics in the analysis of survival data for organophosphorus pesticides. Environ. Sci. Technol. 2005, 39, 8307-8314. [CrossRef] [PubMed]

24. Soderlund, D.M.; Clark, J.M.; Sheets, L.P.; Mullin, L.S.; Piccirillo, V.J.; Sargent, D.; Stevens, J.T.; Weiner, M.L. Mechanisms of pyrethroid neurotoxicity: Implications for cumulative risk assessment. Toxicology 2002, 171, 3-59. [CrossRef]

25. Müller, R.; Berghahn, R.; Hilt, S. Herbicide effects of metazachlor on duckweed (Lemna minor and Spirodela polyrhiza) in test systems with different trophic status and complexity. J. Environ. Sci. Health B 2010, 45, 95-101. [CrossRef] [PubMed]

26. Druckrey, H.; Dischler, W. Dosis-Wirkungsbeziehungen bei der Krebserzeugung durch 4-dimethylaminostilben bei Ratten. Z. Krebsforsch 1963, 65, 272. [CrossRef]

27. Newman, M.C.; McCloskey, J.T. Time-to-event analyses of ecotoxicity data. Ecotoxicology 1996, 5, 187-196. [CrossRef]

28. Kooijman, S.A.L.M. Parametric analyses of mortality rates in bioassays. Water Res. 1981, 15, 107-119.

29. Sánchez-Bayo, F. From simple toxicological models to prediction of toxic effects in time. Ecotoxicology 2009, 18, 343-354. [CrossRef]

30. Ashauer, R.; Boxall, A.B.A.; Brown, C.D. Simulating toxicity of carbaryl to Gammarus pulex after aequential pulsed exposure. Environ. Sci. Technol. 2007, 41, 5528-5534. [CrossRef]

31. Hoang, T.C.; Gallagher, J.S.; Tomasso, J.R.; Klaine, S.J. Toxicity of two pulsed metal exposures to Daphnia magna: Relative effects of pulsed duration-concentration and influence of interpulse period. Arch. Environ. Contam. Toxicol. 2007, 53, 579-589. [CrossRef] 
32. Hano, T.; Ito, K.; Ohkubo, N.; Sakaji, H.; Watanabe, A.; Takashima, K.; Sato, T.; Sugaya, T.; Matsuki, K.; Onduka, T.; et al. Occurrence of neonicotinoids and fipronil in estuaries and their potential risks to aquatic invertebrates. Environ. Pollut. 2019, 252, 205-215. [CrossRef] [PubMed]

33. Ahmed, M.A.I.; Matsumura, F. Synergistic actions of formamidine insecticides on the activity of pyrethroids and neonicotinoids against Aedes aegypti (Diptera: Culicidae). J. Med. Entomol. 2012, 49, 1405-1410. [CrossRef] [PubMed]

34. Cavallaro, M.C.; Morrissey, C.A.; Headley, J.V.; Peru, K.M.; Liber, K. Comparative chronic toxicity of imidacloprid, clothianidin, and thiamethoxam to Chironomus dilutus and estimation of toxic equivalency factors. Environ. Toxicol. Chem. 2017, 36, 372-382. [CrossRef] [PubMed]

35. Macaulay, S.J.; Hageman, K.J.; Alumbaugh, R.E.; Lyons, S.M.; Piggott, J.J.; Matthaei, C.D. Chronic toxicities of neonicotinoids to nymphs of the common New Zealand mayfly Deleatidium spp. Environ. Toxicol. Chem. 2019, 38, 2459-2471. [CrossRef]

36. Stoughton, S.J.; Liber, K.; Culp, J.; Cessna, A. Acute and chronic toxicity of imidacloprid to the aquatic invertebrates Chironomus tentans and Hyalella azteca under constant- and pulse-exposure conditions. Arch. Environ. Contam. Toxicol. 2008, 54, 662-673. [CrossRef]

37. Ieromina, O.; Peijnenburg, W.J.G.M.; de Snoo, G.; Müller, J.; Knepper, T.P.; Vijver, M.G. Impact of imidacloprid on Daphnia magna under different food quality regimes. Environ. Toxicol. Chem. 2014, 33, 621-631. [CrossRef]

38. Roessink, I.; Merga, L.B.; Zweers, H.J.; van den Brink, P.J. The neonicotinoid imidacloprid shows high chronic toxicity to mayfly nymphs. Environ. Toxicol. Chem. 2013, 32, 1096-1100. [CrossRef]

39. van den Brink, P.J.; Smeden, J.M.V.; Bekele, R.S.; Dierick, W.; Gelder, D.D.; Noteboom, M.; Roessink, I. Acute and chronic toxicity of neonicotinoids to nymphs of a mayfly species and some notes on seasonal differences. Environ. Toxicol. Chem. 2016, 35, 128-133. [CrossRef]

40. Uğurlu, P.; Ünlü, E.; Satar, E.İ. The toxicological effects of thiamethoxam on Gammarus kischineffensis (Schellenberg 1937) (Crustacea: Amphipoda). Environ. Toxicol. Pharmacol. 2015, 39, 720-726. [CrossRef]

41. Prosser, R.S.; de Solla, S.R.; Holman, E.A.M.; Osborne, R.; Robinson, S.A.; Bartlett, A.J.; Maisonneuve, F.J.; Gillis, P.L. Sensitivity of the early-life stages of freshwater mollusks to neonicotinoid and butenolide insecticides. Environ. Pollut. 2016, 218, 428-435. [CrossRef]

42. Chandran, N.N.; Fojtova, D.; Blahova, L.; Rozmankova, E.; Blaha, L. Acute and (sub)chronic toxicity of the neonicotinoid imidacloprid on Chironomus riparius. Chemosphere 2018, 209, 568-577. [CrossRef] [PubMed]

43. Demirci, Ö.; Güven, K.; Asma, D.; Öğüt, S.; Uğurlu, P. Effects of endosulfan, thiamethoxam, and indoxacarb in combination with atrazine on multi-biomarkers in Gammarus kischineffensis. Ecotoxicol. Environ. Saf. 2018, 147, 749-758. [CrossRef] [PubMed]

44. Hesketh, H.; Lahive, E.; Horton, A.A.; Robinson, A.G.; Svendsen, C.; Rortais, A.; Dorne, J.L.; Baas, J.; Spurgeon, D.J.; Heard, M.S. Extending standard testing period in honeybees to predict lifespan impacts of pesticides and heavy metals using dynamic energy budget modelling. Sci. Rep. 2016, 6, 37655. [CrossRef] [PubMed]

45. Heard, M.S.; Baas, J.; Dorne, J.-L.; Lahive, E.; Robinson, A.G.; Rortais, A.; Spurgeon, D.J.; Svendsen, C.; Hesketh, H. Comparative toxicity of pesticides and environmental contaminants in bees: Are honey bees a useful proxy for wild bee species? Sci. Total Environ. 2017, 578, 357-365. [CrossRef]

46. Laurino, D.; Porporato, M.; Patetta, A.; Manino, A. Toxicity of neonicotinoid insecticides to honey bees: Laboratory tests. Bull. Insectol. 2011, 64, 107-113.

47. Iwasa, T.; Motoyama, N.; Ambrose, J.T.; Roe, R.M. Mechanism for the differential toxicity of neonicotinoid insecticides in the honey bee, Apis mellifera. Crop Protection 2004, 23, 371-378. [CrossRef]

48. Preetha, G.; Stanley, J.; Suresh, S.; Samiyappan, R. Risk assessment of insecticides used in rice on miridbug, Cyrtorhinus lividipennis Reuter, the important predator of brown planthopper, Nilaparvata lugens (Stal.). Chemosphere 2010, 80, 498-503. [CrossRef]

49. Alkassab, A.T.; Kirchner, W.H. Impacts of chronic sublethal exposure to clothianidin on winter honeybees. Ecotoxicology 2016, 25, 1000-1010. [CrossRef]

50. Martínez, L.C.; Plata-Rueda, A.; Zanuncio, J.C.; Serrao, J.E. Comparative toxicity of six insecticides on the rhinoceros beetle (Coleoptera: Scarabaeidae). Fl. Entomol. 2014, 97, 1056-1062. [CrossRef]

51. Charpentier, G.; Louat, F.; Bonmatin, J.-M.; Marchand, P.A.; Vanier, F.; Locker, D.; Decoville, M. Lethal and sublethal effects of imidacloprid, after chronic exposure, on the insect model Drosophila melanogaster. Environ. Sci. Technol. 2014, 48, 4096-4102. [CrossRef] 
52. D'Ávila, V.A.; Barbosa, W.F.; Guedes, R.N.C.; Cutler, G.C. Effects of spinosad, imidacloprid, and lambda-cyhalothrin on survival, parasitism, and reproduction of the aphid parasitoid Aphidius colemani. J. Econ. Entomol. 2018, 111, 1096-1103. [CrossRef] [PubMed]

53. Husain, D.; Qasim, M.; Saleem, M.; Akhter, M.; Khan, K.A. Bioassay of insecticides against three honey bee species in laboratory conditions. Cercetari Agronomice Moldova 2014, XLVII, 69-79. [CrossRef]

54. Suchail, S.; Guez, D.; Belzunces, L.P. Discrepancy between acute and chronic toxicity induced by imidacloprid and its metabolites in Apis mellifera. Environ. Toxicol. Chem. 2001, 20, 2482-2486. [CrossRef] [PubMed]

55. DEFRA. Assessment of the risk posed to honeybees by systemic pesticides; Department for Environment, Food and Rural Affairs: London, UK, 2007.

56. Preetha, G.; Manoharan, T.; Stanley, J.; Kuttalam, S. Impact of chloronicotinyl insecticide, imidacloprid on egg, egg-larval and larval parasitoids under laboratory conditions. J. Plant Protect. Res. 2010, 50, 535-540. [CrossRef]

57. Carrillo, D.; Peña, J.E.; Rogers, M.E. Relative susceptibility of Haeckeliania sperata (Hymenoptera: Trichogrammatidae) to pesticides used in citrus and ornamental systems in Florida. J. Econ. Entomol. 2009, 102, 905-912. [CrossRef]

58. Rust, M.K.; Reierson, D.A.; Klotz, J.H. Delayed toxicity as a critical factor in the efficacy of aqueous baits for controlling Argentine ants (Hymenoptera: Formicidae). J. Econ. Entomol. 2004, 97, 1017-1024. [CrossRef]

59. Ramakrishnan, R.; Suiter, D.R.; Nakatsu, C.H.; Bennett, G.W. Feeding inhibition and mortality in Reticulitermes flavipes (Isoptera: Rhinotermitidae) after exposure to imidacloprid-treated soils. J. Econ. Entomol. 2000, 93, 422-428. [CrossRef]

60. Niassy, S.; Maniania, N.K.; Subramanian, S.; Gitonga, M.L.; Maranga, R.; Obonyo, A.B.; Ekesi, S. Compatibility of Metarhizium anisopliae isolate ICIPE 69 with agrochemicals used in French bean production. Int. J. Pest Control 2012, 58, 131-137. [CrossRef]

61. Oliveira, R.A.; Roat, T.C.; Carvalho, S.M.; Malaspina, O. Side-effects of thiamethoxam on the brain and midgut of the africanized honeybee Apis mellifera (Hymenopptera: Apidae). Environ. Toxicol. 2014, 29, 1122-1133. [CrossRef]

62. Frantzios, G.; Paptsiki, K.; Sidiropoulou, B.; Lazaridis, I.; Theophilidis, G.; Mavragani-Tsipidou, P. Evaluation of insecticidal and genotoxic effects of imidacloprid and acetochlor in Drosophila melanogaster. J. Appl. Entomol. 2008, 132, 583-590. [CrossRef]

63. Bliss, C.I. The size factor in the action of arsenic upon silkworm larvae. Exp. Biol. 1936, 13, 95-110.

64. Zaller, J.G.; Brühl, C.A. Editorial: Non-target effects of pesticides on organisms inhabiting agroecosystems. Front. Environ. Sci. 2019, 7. [CrossRef]

65. Sánchez-Bayo, F.; Goka, K.; Hayasaka, D. Contamination of the aquatic environment with neonicotinoids and its implication for ecosystems. Front. Environ. Sci. 2016, 4, 71. [CrossRef]

66. Sgolastra, F.; Medrzycki, P.; Bortolotti, L.; Maini, S.; Porrini, C.; Simon-Delso, N.; Bosch, J. Bees and pesticide regulation: Lessons from the neonicotinoid experience. Biol. Conserv. 2020, 241, 108356. [CrossRef]

67. Sánchez-Bayo, F.; Goka, K. Influence of light in acute toxicity bioassays of imidacloprid and zinc pyrithione to zooplankton crustaceans. Aquat. Toxicol. 2006, 78, 262-271.

68. Daam, M.A.; Santos Pereira, A.C.; Silva, E.; Caetano, L.; Cerejeira, M.J. Preliminary aquatic risk assessment of imidacloprid after application in an experimental rice plot. Ecotoxicol. Environ. Saf. 2013, 97, 78-85. [CrossRef]

69. Morrissey, C.A.; Mineau, P.; Devries, J.H.; Sánchez-Bayo, F.; Liess, M.; Cavallaro, M.C.; Liber, K. Neonicotinoid contamination of global surface waters and associated risk to aquatic invertebrates: A review. Environ. Int. 2015, 74, 291-303. [CrossRef]

70. Pisa, L.W.; Amaral-Rogers, V.; Belzunces, L.P.; Bonmatin, J.M.; Downs, C.A.; Goulson, D.; Kreutzweiser, D.P.; Krupke, C.; Liess, M.; McField, M.; et al. Effects of neonicotinoids and fipronil on non-target invertebrates. Environ. Sci. Pollut. Res. 2015, 22, 68-102. [CrossRef]

71. Gibbons, D.; Morrissey, C.; Mineau, P. A review of the direct and indirect effects of neonicotinoids and fipronil on vertebrate wildlife. Environ. Sci. Pollut. Res. 2015, 22, 103-118. [CrossRef]

72. Rinkevich, F.D.; Margotta, J.W.; Pittman, J.M.; Danka, R.G.; Tarver, M.R.; Ottea, J.A.; Healy, K.B. Genetics, synergists, and age affect insecticide sensitivity of the honey bee, Apis mellifera. PLoS ONE 2015, 10, e0139841. [CrossRef]

73. Paine, T.D.; Hanlon, C.C.; Byrne, F.J. Potential risks of systemic imidacloprid to parasitoid natural enemies of a cerambycid attacking Eucalyptus. Biol. Control 2011, 56, 175-178. [CrossRef] 
74. Tremolada, P.; Mazzoleni, M.; Saliu, F.; Colombo, M.; Vighi, M. Field trial for evaluating the effects on honeybees of corn sown using cruiser@and Celest®treated seeds. Bull. Environ. Contam. Toxicol. 2010, 85, 229-234. [CrossRef] [PubMed]

75. Preetha, G.; Stanley, J.; Suresh, S.; Kuttalam, S.; Samiyappan, R. Toxicity of selected insecticides to Trichogramma chilonis: Assessing their safety in the rice ecosystem. Phytoparasitica 2009, 37, 209-215. [CrossRef]

76. Rill, S.M.; Grafton-Cardwell, E.E.; Morse, J.G. Effects of two insect growth regulators and a neonicotinoid on various life stages of Aphytis melinus (Hymenoptera: Aphelinidae). BioControl 2008, 53, 579. [CrossRef]

77. Prabhaker, N.; Castle, S.J.; Naranjo, S.E.; Toscano, N.C.; Morse, J.G. Compatibility of two systemic neonicotinoids, imidacloprid and thiamethoxam, with various natural enemies of agricultural pests. J. Econ. Entomol. 2011, 104, 773-781. [CrossRef]

78. Wang, Y.; Yu, R.; Zhao, X.; Chen, L.; Wu, C.; Cang, T.; Wang, Q. Susceptibility of adult Trichogramma nubilale (Hymenoptera: Trichogrammatidae) to selected insecticides with different modes of action. Crop Protection 2012, 34, 76-82. [CrossRef]

79. Furlan, L.; Pozzebon, A.; Duso, C.; Simon-Delso, N.; Sánchez-Bayo, F.; Marchand, P.A.; Codato, F.; Lexmond, M.B.v.; Bonmatin, J.-M. An update of the Worldwide Integrated Assessment (WIA) on systemic insecticides. Part 3: Alternatives to systemic insecticides. Environ. Sci. Pollut. Res. 2018, in press. [CrossRef]

80. Benton, E.P.; Grant, J.F.; Nichols, R.J.; Webster, R.J.; Schwartz, J.S.; Bailey, J.K. Risk assessment of imidacloprid use in forest settings on the aquatic macroinvertebrate community. Environ. Toxicol. Chem. 2017, 36, 3108-3119. [CrossRef]

81. Aslund, M.W.; Winchell, M.; Bowers, L.; McGee, S.; Tang, J.; Padilla, L.; Greer, C.; Knopper, L.; Moore, D.R.J. Ecological risk assessment for aquatic invertebrate communities exposed to imidacloprid due to labeled agricultural and non-agricultural uses in the United States. Environ. Toxicol. Chem. 2017, 36, 1375-1388. [CrossRef]

82. van Dijk, T.C.; van Staalduinen, M.A.; van der Sluijs, J.P. Macro-invertebrate decline in surface water polluted with imidacloprid. PLoS ONE 2013, 8, e62374. [CrossRef]

83. Yamamuro, M.; Komuro, T.; Kamiya, H.; Kato, T.; Hasegawa, H.; Kameda, Y. Neonicotinoids disrupt aquatic food webs and decrease fishery yields. Science 2019, 366, 620-623. [CrossRef] [PubMed]

84. Pisa, L.; Goulson, D.; Yang, E.-C.; Gibbons, D.; Sánchez-Bayo, F.; Mitchell, E.; Aebi, A.; Sluijs, J.v.d.; MacQuarrie, C.J.K.; Giorio, C.; et al. An update of the Worldwide Integrated Assessment (WIA) on systemic insecticides. Part 2: Impacts on organisms and ecosystems. Environ. Sci. Pollut. Res. 2017, in press. [CrossRef] [PubMed]

85. Sánchez-Bayo, F.; Tennekes, H.A. Assessment of ecological risks of agrochemicals requires a new framework. Environ. Risk Assess. Remed. 2017, 1, 20-28. [CrossRef]

86. Douglas, M.R.; Sponsler, D.B.; Lonsdorf, E.V.; Grozinger, C.M. County-level analysis reveals a rapidly shifting landscape of insecticide hazard to honey bees (Apis mellifera) on US farmland. Sci. Rep. 2020, 10, 797. [CrossRef] [PubMed]

87. Goulson, D.; Thompson, J.; Croombs, A. Rapid rise in toxic load for bees revealed by analysis of pesticide use in Great Britain. PeerJ 2018, 6, e5255. [CrossRef] [PubMed]

88. Sánchez-Bayo, F.; Wyckhuys, K.A.G. Worldwide decline of the entomofauna: A review of its drivers. Biol. Conserv. 2019, 232, 8-27. [CrossRef]

89. Beketov, M.A.; Kefford, B.J.; Schäfer, R.B.; Liess, M. Pesticides reduce regional biodiversity of stream invertebrates. PNAS 2013, 110, 11039-11043. [CrossRef]

90. Munz, N.A.; Burdon, F.J.; de Zwart, D.; Junghans, M.; Melo, L.; Reyes, M.; Schönenberger, U.; Singer, H.P.; Spycher, B.; Hollender, J.; et al. Pesticides drive risk of micropollutants in wastewater-impacted streams during low flow conditions. Water Res. 2017, 110, 366-377. [CrossRef]

91. Agostini, M.G.; Roesler, I.; Bonetto, C.; Ronco, A.E.; Bilenca, D. Pesticides in the real world: The consequences of GMO-based intensive agriculture on native amphibians. Biol. Conserv. 2020, 241, 108355. [CrossRef]

92. Nakanishi, K.; Uéda, T.; Yokomizo, H.; Hayashi, T.I. Effects of systemic insecticides on the population dynamics of the dragonfly Sympetrum frequens in Japan: Statistical analyses using field census data from 2009 to 2016. Sci. Total Environ. 2020, 703, 134499. [CrossRef]

93. Hallmann, C.A.; Foppen, R.P.B.; van Turnhout, C.A.M.; de Kroon, H.; Jongejans, E. Declines in insectivorous birds are associated with high neonicotinoid concentrations. Nature 2014, 511, 341-343. [CrossRef] [PubMed]

94. Brühl, C.A.; Zaller, J.G. Biodiversity decline as a consequence of an inappropriate environmental risk assessment of pesticides. Front. Environ. Sci. 2019, 7, 177. [CrossRef] 
95. Schafer, R.B.; Liess, M.; Altenburger, R.; Filser, J.; Hollert, H.; Roß-Nickoll, M.; Schaffer, A.; Scheringer, M. Future pesticide risk assessment: Narrowing the gap between intention and reality. Environ. Sci. Eur. 2019, 31, 21. [CrossRef]

96. Topping, C.J.; Aldrich, A.; Berny, P. Overhaul environmental risk assessment for pesticides. Science 2020, 367, 360. [CrossRef] [PubMed] 